\title{
Bio-Guided Isolation of Two New Hypoglycemic Triterpenoid Saponins from Polygonum capitatum
}

\author{
Doudou Huang ${ }^{1,2, *}$ \\ Zenan Du ${ }^{1,2, *}$ \\ Yanhong Chen ${ }^{3, *}$ \\ Zhiying Dong' \\ Xiujuan Wang' \\ Mengshuang $\mathrm{Li}^{\prime}$ \\ Feng Zhang ${ }^{3, *}$ \\ Wansheng Chen ${ }^{2,3}$ \\ Lianna Sun'
}

'Department of TCM Processing, Shanghai University of Traditional Chinese Medicine, Shanghai, People's Republic of China; ${ }^{2}$ Institute of Chinese Materia Medica, Shanghai University of Traditional Chinese Medicine, Shanghai, People's Republic of China; ${ }^{3}$ Department of Pharmacy, Changzheng Hospital, Second Military Medical University, Shanghai, People's Republic of China

*These authors contributed equally to this work
Correspondence: Lianna Sun;

Wansheng Chen

Tel/Fax +86-2I-5I3222II

Email sssnmr@163.com;

chenwansheng@smmu.edu.cn
Purpose: Diabetes is a common disease caused by a combination of genetic and environmental factors, which was the top three diseases threatening human health. Therefore, it is necessary to seek more efficient hypoglycemic drugs. The main objective of this study was to investigate the potential hypoglycemic effects of compounds from Polygonum capitatum.

Materials and Methods: Our experiments were divided into three steps: (1) $\alpha$-amylase test and oral starch tolerance test (OSTT) for screening the biological extract part of P. capitatum; (2) chemical isolation and identification using various separation techniques, and spectrum methods; and (3) evaluation of $\alpha$-amylase inhibitory activity of isolates and in silico analysis for mechanism investigation.

Results: The n-butanol fractioned part of $P$. capitatum was confirmed to be the biological part according to $\alpha$-amylase test. Then, two new triterpenoid saponins were isolated from the n-butanol part, which were also the first isolated triterpenoid saponins from $P$. capitatum. The activities of compounds 1 and 2 against $\alpha$-amylase were $51.9 \pm 2.8 \%$ and $38.1 \pm 2.2 \%$, respectively, which was consistent with the molecular docking analysis. In which, $\mathbf{1}$ and $\mathbf{2}$ showed the binding affinity energy for $\alpha$-amylase was $-9.4 \mathrm{kcal} / \mathrm{mol}$ and $-7.8 \mathrm{kcal} / \mathrm{mol}$, respectively. Conclusion: Two new triterpenoid saponins were firstly isolated from $P$. capitatum, and displays potency as a hypoglycemic agent through blocking $\alpha$-amylase.

Keywords: $\alpha$-amylase, Polygonum capitatum, triterpene saponins, hypoglycemic

\section{Introduction}

Clinical studies show that postprandial hyperglycemia is a key risk factor for cardiovascular disease in diabetics, ${ }^{1}$ thus, controlling postprandial blood glucose is of great significance in reducing the complications of diabetes. The complex carbohydrates break down to glucose, through $\alpha$-amylase enzymes, and lead to the rapid absorption of glucose into the bloodstream leading to hyperglycemia. ${ }^{2}$ Pancreatic $\alpha$-amylase is a key enzyme in catalyzing the initial step of complex carbohydrates (starch and glycogen) into shorter oligosaccharides, which are degraded to glucose by $\alpha$-amylase in the small intestine. ${ }^{3} \alpha$-Amylase inhibitors mainly inhibit the hydrolysis of polysaccharides into glucose by competing with the maltase and $\alpha$-amylase on the surface of the small intestine mucosa, thereby delaying the absorption of sugars, and reducing postprandial hyperglycemia, the stimulation of pancreatic islet $\beta$ cells, and the insulin secretion. ${ }^{4}$ So, those suitable inhibitors were considered to be used to control and regulate the activity of $\alpha$ amylase for the treatment of diabetes. However, there are too few types of $\alpha$ amylase inhibitors in clinical applications. Moreover, there are several adverse reactions of $\alpha$-amylase inhibitors in clinical uses, such as gastrointestinal 
discomfort (bloating, abdominal pain) and so on. ${ }^{5,6}$ Therefore, looking for high-efficiency $\alpha$-amylase inhibitors from natural products is attracting more and more attention. $^{7,8}$

Polygonum capitatum (Polygonum capitatum Buch.Ham. ex D. Don) belongs to the Polygonaceae, genus Polygonum, mainly distributed in Hunan, Hubei, Sichuan, and Guizhou provinces in China. Previous studies have showed that $P$. capitatum has a significant inhibitory activity against $\alpha$-glucosidase, and insulin sensitization effect. ${ }^{9,10}$ Our previous study has revealed $P$. capitatum possessed $\alpha$-amylase inhibition effect. ${ }^{11}$ As a continuous study, we used $\alpha$-amylase test and OSTT experiment to bio-guided trace the effect fraction of $P$. capitatum, which identified two new triterpenoid saponins with anti- $\alpha$-amylase activity. Moreover, the underlying plausible molecular targets were further explored by molecular docking analysis.

\section{Materials and Methods}

\section{Materials}

The aerial part of $P$. capitatum was collected from Bozhou, Anhui province in China in May 2008. The plant was identified and deposited in School of Pharmacy of Second Military Medical University (PC20080517). Distilled organic solvents used for extraction and purification included methanol, ethanol, petroleum ether, ethyl acetate, n-butanol, and acetonitrile, while the chemicals used for spectroscopic analysis were deuterated grades. Chromatographic separations were conducted on Silica gel (200-300 and 300-400 mesh) (Sino Pharm, Shanghai, China), ODS RP-18 (50 $\mu \mathrm{m})$ (Merck, Darmstadt, Germany), and HL-20 (GE Sephadex, MA, USA) columns. Silica GF254 plates $(0.25 \mathrm{~mm}$, Aladdin, Shanghai, China) and ODS RP-18 F254 $(0.25 \mathrm{~mm}$, Merck) plates were used for thin-layer chromatography (TLC) and detection achieved by spraying with $5 \%$ $\mathrm{H}_{2} \mathrm{SO}_{4}$ in ethanol (v/v), followed by heating.

$\alpha$-Amylase was purchased from Sigma-Aldrich (\#A4268, Saint Louis, MO, USA). 6-week-old male ICR mice (body weight $22 \pm 3 \mathrm{~g}$ ) were obtained from Shanghai SLAC Laboratory Animal Co. Ltd and kept under controlled environmental conditions at room temperature (22 $\left.\pm 2{ }^{\circ} \mathrm{C}\right)$ and humidity $(50 \pm 10 \%)$. The $12 / 12 \mathrm{~h} \mathrm{light/dark}(8$ am-8 pm) cycle was maintained throughout the study. Blood glucose test strips were purchased from Major Biosystem Corp (Taipei, China). Starch was obtained from Shandong Shengqi Biology Co., Ltd, and acarbose was purchased from Bayer (Leverkusen, Germany).

\section{OSTT (Oral Starch Tolerance Test)}

Forty mice were divided into 5 groups $(n=8)$ : the control group (Con, water); P. capitatum group (PC, $1200 \mathrm{mg} / \mathrm{kg}$ ), n-butanol fraction group (PCB, $400 \mathrm{mg} / \mathrm{kg}$ ), model group (Starch, $2000 \mathrm{mg} / \mathrm{kg}$ ), and positive group (Acarbose, 25 $\mathrm{mg} / \mathrm{kg}$ ). Briefly, forty ICR mice were reared adaptively for 2-3 days, and randomly grouped according to body weight $(n=8)$. Food and litter were removed 12 hours before the experiment. Acarbose (50 mg), PC (1200 mg), and PCB (200 mg) were dissolved in $5 \mathrm{~mL} 0.5 \%$ sodium carboxymethyl cellulose $(\mathrm{CMCNa})$, respectively. Then, all above samples were mixed with $2.5 \mathrm{~g} / \mathrm{kg}$ starch in equal volume and then administered by gavage together. The administration volume was $0.1 \mathrm{~mL} / 10 \mathrm{~g}$ body weight, and the control group was given an equal volume of vehicle. Blood glucose was measured at $30 \mathrm{~min}, 60 \mathrm{~min}$ and 120 min after starch administration. The blood glucose before administration was recorded as $0 \mathrm{~min}$. The animal experiments were approved by the Ethics Committee of Second Military Medical University (Shanghai, China), according to the Guide for the Care and Use of Laboratory Animal published by the National Institutes of Health (Bethesda, MD, USA).

\section{$\alpha$-Amylase Activity}

Six groups, including 5 sample groups, and positive group (acarbose), were put in 96-well plates, each with 6 replicate wells. The operation method is as follows: $25 \mu \mathrm{L}$ sample solution, distilled water, and $12.5 \mu \mathrm{L} \alpha$-amylase solution $(27.8 \mu \mathrm{g} / \mathrm{mL})$ were transferred into 96-well plates, and incubated at $37{ }^{\circ} \mathrm{C}$ for $10 \mathrm{~min}$. Then, $12.5 \mu \mathrm{L}$ starch solution was added to each well, and incubated at $37{ }^{\circ} \mathrm{C}$ for $10 \mathrm{~min}$. After that, $500 \mu \mathrm{L}$ color reagent was added to each well to stop the reaction. The absorbance (A) was measured at $630 \mathrm{~nm}$ wavelength, which reflects the activity of amylase. The calculation formula of the inhibition rate $(\%)$ is as follows:

Inhibition rate $(\%)=[1-(\mathrm{A}$ sample without enzyme-A sample with enzyme)/(A blank control without enzyme-A blank control with enzyme) $] \times 100 \%$.

\section{Kinetic Study of $\alpha$-Amylase Inhibition}

In this study, PCB was selected to perform the kinetic study based on previous study. ${ }^{12}$ In brief, $12.5 \mu \mathrm{L}$ of $\alpha$ amylase solution $(27.8 \mu \mathrm{g} / \mathrm{mL})$ together with $25 \mu \mathrm{L}$ of the 
PCB $(600 \mu \mathrm{g} / \mathrm{mL})$ was incubated for $10 \mathrm{~min}$ at $25{ }^{\circ} \mathrm{C}$ while the control group was incubated with $12.5 \mu \mathrm{L}$ of $0.5 \% \mathrm{CMCNa}$. $12.5 \mu \mathrm{L}$ of various concentrations of starch solution $(0.3125 \mathrm{mg} / \mathrm{mL}, 0.625 \mathrm{mg} / \mathrm{mL}, 1.25 \mathrm{mg} / \mathrm{mL}, 2.5$ $\mathrm{mg} / \mathrm{mL}, 5.0 \mathrm{mg} / \mathrm{mL}$ ) were added into the reaction system incubating for $10 \mathrm{~min}$ at $25^{\circ} \mathrm{C}$, which were followed by boiling for $5 \mathrm{~min}$ with $100 \mu \mathrm{L}$ of 3,5-dinitrosalicylic acid (DNS) for terminating the reaction. The reducing sugars were determined based on maltose standard curve using spectrophotometry $(630 \mathrm{~nm})$. A Lineweaver-Burk double reciprocal curve was plotted using $1 /[\mathrm{S}]$ as the abscissa and $1 / \mathrm{v}$ as the ordinate to determine the type of inhibition of PCB to $\alpha$-amylase, in which $\mathrm{v}$ is reaction velocity and $[\mathrm{S}]$ is substrate concentration.

\section{Isolation of Components of $P$. capitatum}

Air-dried P. capitatum (18 kg) was ground into powder and extracted with $80 \%$ ethanol, and concentrated with a rotary evaporator under pressure to yield crude $(2730 \mathrm{~g})$. The crude was suspended in distilled water $(1.5 \mathrm{~L})$, and fractioned with petroleum ether (PCP), ethyl acetate (PCE), n-butanol (PCB), and water (PCW). The n-butanol $(800 \mathrm{~g})$ fraction was subject to microporous resin (3000 g), and eluted with distilled water, $10 \%$ ethanol, $30 \%$ ethanol, $70 \%$ ethanol, and $95 \%$ ethanol, to obtain five fractions (Fr.1-Fr.5) based on TLC analysis. Fr.3 (22.07 g) was further fractionated via MCI column chromatography, and eluted with distilled water, 10\% methanol, 30\% methanol, 50\% methanol, 70\% methanol, and 95\% methanol, to obtain seven fractions (Fr.3-1-Fr.3-7). The Fr.3-4 (287 mg) subfraction was purified via column chromatography on an ODS RP-18 column and eluted using $\mathrm{H}_{2} \mathrm{O}-$ $\mathrm{MeOH}$ at a gradient of $10 \%(\mathrm{v} / \mathrm{v})$ to yield compounds $\mathbf{1}$ (5.7 $\mathrm{mg})$ and $2(5.5 \mathrm{mg})$.

\section{Molecular Docking}

The three-dimensional (3D) structure of $\alpha$-amylase (PDB id: $1 \mathrm{DHK}$ ) were obtained from protein data bank. PyMOL v2.5 was used to analyze the protein structure, with crystallographic waters removing. After that, autodocktool1.5.6 was used to add hydrogen atoms in previous structure with GA run 10. The 3D interactions of the docked ligands were visualized using autodocktool-1.5.6, to analyze their relative positional relationships.

\section{Statistical Analysis}

Data are expressed as the mean $\pm \mathrm{SD}$ for this research. Statistical comparisons of the results were carried out using one-way analysis of variance (ANOVA), with significantly different at $p<0.05$ by using post hoc Tukey's test.

\section{Results \\ $\alpha$-Amylase Inhibition Screening}

In the search for phytocomponents with $\alpha$-amylase and $\alpha$ glucosidase inhibition activities, ethanol extracts of $P$. capitatum $(\mathrm{PC})$ and its fractioned parts (PCP, PCE, PCB, and $\mathrm{PCW}$ ) were first selected for biological evaluation. In our research, all samples were prepared in $139 \mu \mathrm{g} / \mathrm{mL}$ (Table 1), and the inhibitory rate of the positive control drug acarbose was recorded as $100 \%$. From Table 1, PC and PCB showed strong $\alpha$-amylase inhibition. Especially for PCB parts, the $\alpha$-amylase inhibitory values were $147.37 \pm 10.82 \%$, which showed stronger activity than positive drugs.

From the results of in vitro screening, it can be preliminarily determined that the n-butanol fractioned part of $P$. capitatum has strong enzyme inhibitory activity on $\alpha$ amylase, which guided us to explore the active components. The mode of inhibition of $\alpha$-amylase activity by the PCB was determined using the Lineweaver-Burk plot which showed that PCB displayed a noncompetitive inhibition of the enzyme activity (Figure 1).

\section{Inhibition of PC and PCB in Starch Digestion}

From the above results, PCB has showed a potential hypoglycemic effect. In order to confirm this hypothesis, we did the experimental test for lowering blood glucose with extract of $P$. capitatum (PC) and its fractioned parts (PCB) in starch-induced hyperglycemia mice. OSTT showed that PC and PCB exerted glucose inhibition as compared with the model group (Table 2), especially for the PCB treatment, the glucose levels were very close to acarbose from $30 \mathrm{~min}$ to $120 \mathrm{~min}$. And the altered trend of

Table I PC and Different Fractions Against $\alpha$-Amylase and $\alpha$ Glucosidase Inhibitory Effect $(n=3)$

\begin{tabular}{|l|c|}
\hline Name & a- Amylase Inhibition (139 $\mathbf{~ g / m L , ~ \% ) ~}$ \\
\hline PC & $122.24 \pm 16.86$ \\
PCP & $60.86 \pm 13.24$ \\
PCE & $92.48 \pm 10.41$ \\
PCB & $147.37 \pm 10.82$ \\
PCW & $3.71 \pm 1.23$ \\
Acarbose & 100 \\
\hline
\end{tabular}




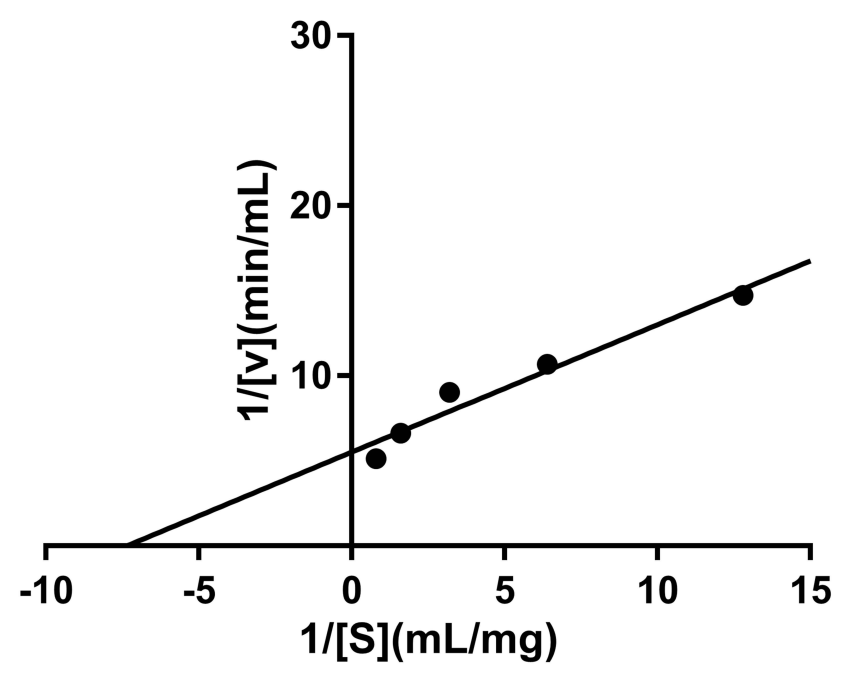

Figure I Inhibition kinetics of $P$. capitatum n-butanol fraction (PCB) against $\alpha$ amylase.

blood glucose levels shown as AUC also confirmed PCB was very potent when compared with the reference drug acarbose (Table 2), suggesting the beneficial effect of PCB on suppressing starch digestion.

\section{Structure Characterization of Compounds I and 2}

Compound 1 (Figure 2), isolated as a white powder, was determined to have a molecular formula of $\mathrm{C}_{48} \mathrm{H}_{78} \mathrm{O}_{20}$ by its HRESIMS (m/z 997.4984, $[\mathrm{M}+\mathrm{Na}]^{+}$calc. 974.5091) and NMR data analysis (Supplementary Figure S1). The IR absorptions suggested the presence of hydroxyl (3422 $\mathrm{cm}^{-1}$ ), and carbonyl $\left(1738 \mathrm{~cm}^{-1}\right)$. The ${ }^{1} \mathrm{H}-\mathrm{NMR}$ spectrum (Table 3, Supplementary Figure S2) of 1 displayed several characteristic proton signals for seven methyl proton signals at $\delta_{\mathrm{H}} 1.82(3 \mathrm{H}, \mathrm{s}), 1.74(3 \mathrm{H}, \mathrm{s})$, $1.72(3 \mathrm{H}, \mathrm{s}), 1.09(3 \mathrm{H}, \mathrm{s}), 0.86(3 \mathrm{H}, \mathrm{d}, J=6.4 \mathrm{~Hz}), 0.93$ $(3 \mathrm{H}, \mathrm{s})$, and $1.69(3 \mathrm{H}, \mathrm{d}, J=6.4 \mathrm{~Hz})$. In addition, an olefinic proton signal at $\delta_{\mathrm{H}} 5.51(1 \mathrm{H}, \mathrm{d}, J=6.8 \mathrm{~Hz})$, and three anomeric methines at $\delta_{\mathrm{H}} 6.13(1 \mathrm{H}, \mathrm{d}, J=7.8 \mathrm{~Hz})$, $5.84(1 \mathrm{H}, \mathrm{brs}), 4.96(1 \mathrm{H}, \mathrm{d}, J=1.8 \mathrm{~Hz})$ were observed in the ${ }^{1} \mathrm{H}$-NMR spectrum. In the ${ }^{13} \mathrm{C}-\mathrm{NMR}$ and DEPT NMR spectra of 1 (Supplementary Figures S3 and S4), seven primary carbon signals at $\delta_{\mathrm{C}} 16.6,18.8,17.8,24.2,21.7$, 18.8 , and 19.8 were readily assigned to seven methyl groups, one quaternary carbon at $\delta_{\mathrm{C}} 176.2$ was assigned to carbonyl groups, and two olefinic carbon signals at $\delta_{\mathrm{C}}$ 126.8 and 138.2 were detected. Moreover, in the ${ }^{13} \mathrm{C}-\mathrm{NMR}$ spectra of 1 , three signals at $\delta_{\mathrm{C}} 96.9,105.4$, and 102.7 were assigned to the anomeric carbons for two glucoses and one ${ }_{\mathrm{L}}$-rhamnose with the aid of HMQC and ${ }^{1} \mathrm{H}-{ }^{1} \mathrm{H}$ COSY spectrum (Figure 3, Supplementary Figures S5 and S6). The configurations of anomeric protons were defined as $\alpha$-glucose, $\beta$-glucose, and $\alpha$-rhamnose based on the coupling constant at $\delta_{\mathrm{H}} 4.96(1 \mathrm{H}, \mathrm{d}, J=1.8 \mathrm{~Hz}), 6.13$ $(1 \mathrm{H}, \mathrm{d}, J=7.8 \mathrm{~Hz}), 5.84(1 \mathrm{H}$, brs $)$, respectively. The sugar residues were further identified as $\mathrm{D}^{-}$-glucose and $\mathrm{L}_{\mathrm{L}}$-rhamnose according to acid hydrolysis and TLC comparison based on the methods previously reported. The ${ }^{1} \mathrm{H}-\mathrm{NMR}$ and ${ }^{13} \mathrm{C}-\mathrm{NMR}$ spectroscopic data suggested that the skeleton of $\mathbf{1}$ was very similar to Terminolic acid, ${ }^{13}$ except for the presence of sugar moieties in $\mathbf{1}$. The double bond was located between $\mathrm{C}-12$ and $\mathrm{C}-13$ in view of the HMBC correlations of H-18 $\left(\delta_{\mathrm{H}} 2.49\right)$ with $\mathrm{C}-12\left(\delta_{\mathrm{C}} 126.8\right)$ and $\mathrm{C}-13\left(\delta_{\mathrm{C}} 138.2\right)$ (Supplementary Figure S7). The chemical shifts of C-6, C-2 and C-3 at $\delta_{\mathrm{C}} 67.9,69.5$ and 78.7 suggested the equatorial position of the hydroxyl groups at C-6, C-2 and C-3. In the NOESY spectrum of $\mathbf{1}$, the obvious cross signals of $\mathrm{H}-2\left(\delta_{\mathrm{H}} 4.65\right) / \mathrm{H}-25\left(\delta_{\mathrm{H}} 1.74\right), \mathrm{H}-2$ $\left(\delta_{\mathrm{H}} 4.65\right) / \mathrm{H}-23\left(\delta_{\mathrm{H}} 1.82\right), \mathrm{H}-5\left(\delta_{\mathrm{H}} 1.98\right) / \mathrm{H}-24\left(\delta_{\mathrm{H}} 4.06\right)$ and $\mathrm{H}-3\left(\delta_{\mathrm{H}} 4.08\right) / \mathrm{H}-5\left(\delta_{\mathrm{H}} 1.98\right)$ further confirmed the stereochemistries of $\mathrm{H}-2, \mathrm{H}-3$ and the presence of an oxygen atom connected to $\mathrm{C}-24$, while the correlation between H-6 ( $\delta_{\mathrm{H}}$ 5.07) and $\mathrm{H}-24\left(\delta_{\mathrm{H}} 4.06\right)$ in the NOESY spectrum verified the stereochemistry of H-6. A glucose residue was confirmed to be connected to C-28 of the aglycone due to the HMBC correlation between the anomeric proton at $\delta_{\mathrm{H}} 6.13(1 \mathrm{H}, \mathrm{d}, J=7.8 \mathrm{~Hz})$ and the methylene signal at $\delta_{\mathrm{C}} 176.2(\mathrm{C}-28)$. The other two sugar

Table 2 The Lowering Blood Glucose of PC and PCB in Starch-Induced Mice $(\bar{x} \pm s, n=8)$

\begin{tabular}{|l|c|c|c|c|c|}
\hline Group & $\mathbf{0}$ min & $\mathbf{3 0}$ min & $\mathbf{6 0}$ min & I20 min & AUC \\
\hline Con & $3.3 \pm 0.2$ & $3.2 \pm 0.2$ & $3.6 \pm 0.4$ & $3.3 \pm 0.2$ & $6.3 \pm 0.3$ \\
Model $(2 \mathrm{~g} / \mathrm{kg})$ & $3.4 \pm 0.5$ & $6.9 \pm 0.7^{\# \#}$ & $11.4 \pm 0.5^{\# \#}$ & $6.4 \pm 0.4^{\# \#}$ & $16.1 \pm 0.2$ \\
PC $(1.2 \mathrm{~g} / \mathrm{kg})$ & $3.4 \pm 0.2$ & $3.4 \pm 0.4^{* *}$ & $4.2 \pm 0.6^{* *}$ & $3.4 \pm 0.5^{* *}$ & $7.4 \pm 0.3$ \\
PCB $(400 \mathrm{mg} / \mathrm{kg})$ & $3.2 \pm 0.4$ & $3.3 \pm 0.6^{* *}$ & $3.5 \pm 0.7^{* *}$ & $3.4 \pm 0.3^{* *}$ & $6.7 \pm 0.4$ \\
Acarbose $(25 \mathrm{mg} / \mathrm{kg})$ & $3.4 \pm 0.5$ & $3.7 \pm 0.7^{* *}$ & $3.1 \pm 0.7^{* *}$ & $3.1 \pm 0.5^{* *}$ & $6.6 \pm 0.5$ \\
\hline
\end{tabular}

Notes: ${ }^{\#} p<0.01$ compared with Con; ${ }^{* *} p<0.01$ compared with Model. 


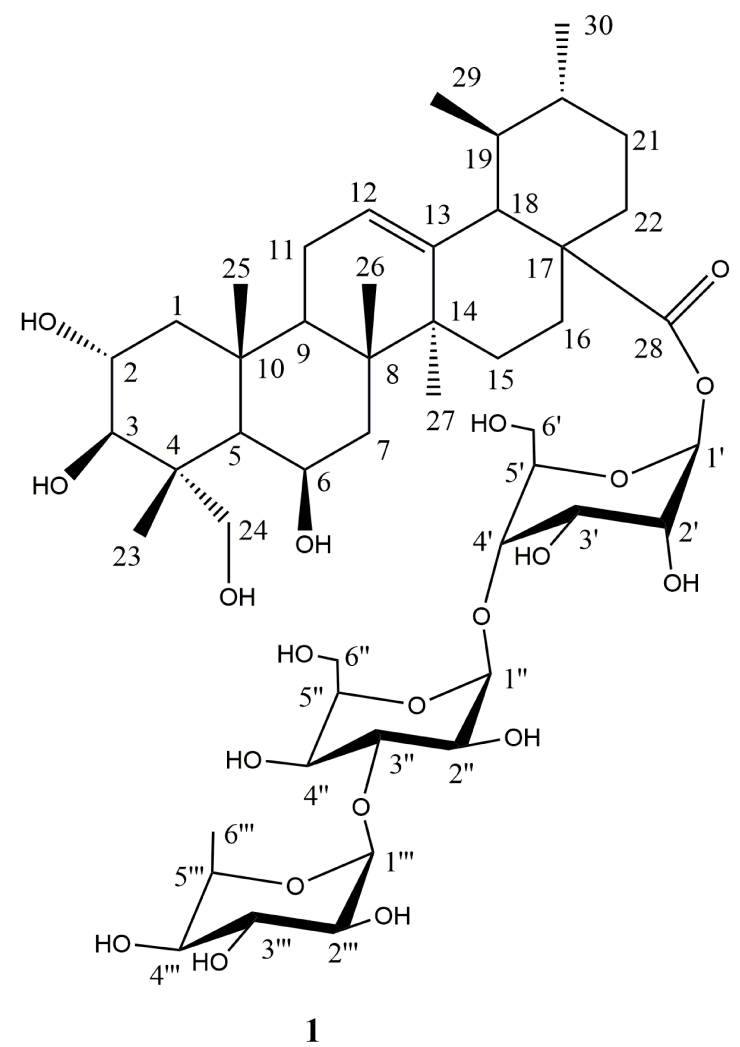

Figure $\mathbf{2}$ Structures of compounds $\mathbf{I}$ and $\mathbf{2}$.

moieties were verified by the following important $\mathrm{HMBC}$ correlations from $\mathrm{H}-1$ " $\left(\delta_{\mathrm{H}} 4.96\right)$ of Glc-1" to C-4' $\left(\delta_{\mathrm{C}}\right.$ $71.5)$, and $\mathrm{H}-1{ }^{\prime \prime \prime}\left(\delta_{\mathrm{H}} 5.84\right)$ of Rha to C-4" $\left(\delta_{\mathrm{C}} 78.8\right)$ of Glc1" (Figure 3). Finally, compound $\mathbf{1}$ was established as $2 \alpha, 3 \beta, 6 \beta, 24$-tetrahydroxy-olean-13-en-28-oic acid 28-O$\alpha{ }_{-\mathrm{L}}$-rhamnopyranosyl-( $(1 \rightarrow 3)-\mathrm{O}-\alpha_{-}{ }^{-}{ }^{-}$glucopyranosyl$(1 \rightarrow 4)-\mathrm{O}-\beta{ }_{-}-$-glucopyranosyl ester.

Compound 2 (Figure 2), isolated as a white powder, was determined to have a molecular formula of $\mathrm{C}_{48} \mathrm{H}_{78} \mathrm{O}_{19}$ by its HRESIMS (m/z 959.5227 [M+H] $]^{+}$, calc. 958.5137) and NMR data analysis (Supplementary Figure S8). The IR absorptions suggested the presence of hydroxyl (3421 $\left.\mathrm{cm}^{-1}\right)$, and carbonyl $\left(1738 \mathrm{~cm}^{-1}\right)$. Comparison of the ${ }^{1} \mathrm{H}-\mathrm{NMR}$ and ${ }^{13} \mathrm{C}-\mathrm{NMR}$ data (Table 3; Supplementary

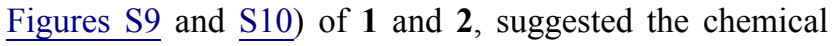
structures of these two compounds were very similar, except the obvious chemical shift of C-6. The upfield chemical shift of C-6 at $\delta_{\mathrm{C}} 34.1$ in 2 suggested the hydroxyl group was replaced with a hydrogen compared with $\mathbf{1}$, which was confirmed by the appearance of secondary carbon at $\delta_{\mathrm{C}} 34.1$ in the DEPT and HMQC spectrum (Supplementary Figures S11 and S12). The double methyl proton signal assigned to $\mathrm{H}-29$ at $\delta_{\mathrm{H}} 0.93(3 \mathrm{H}, \mathrm{d}, J=3.12$

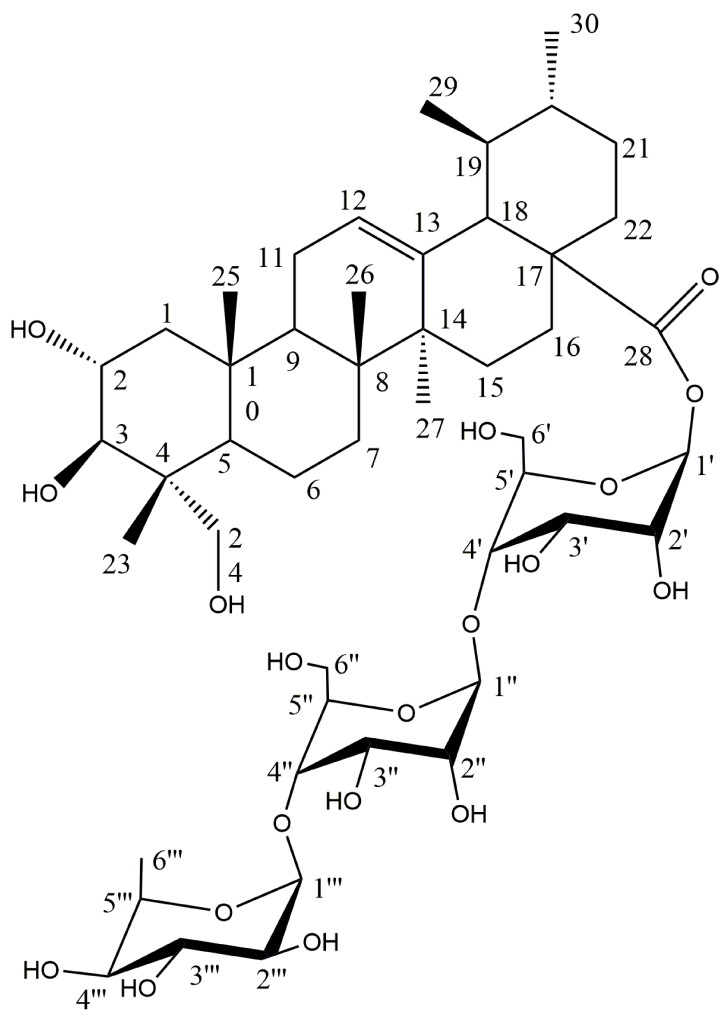

2
$\mathrm{Hz})$ showed an $\mathrm{HMBC}$ correlation with $\mathrm{C}-18\left(\delta_{\mathrm{C}} 54.1\right)$, while another double methyl proton signal assigned to $\mathrm{H}-30$ at $\delta_{\mathrm{H}} 0.89(3 \mathrm{H}, \mathrm{d}, J=2.40 \mathrm{~Hz})$ exhibited $\mathrm{HMBC}$ correlations with C-19 $\left(\delta_{\mathrm{C}} 40.2\right)$ and C-21 ( $\left.\delta_{\mathrm{C}} 31.7\right)$, suggesting the ursane-type aglycone of 2 (Supplementary Figure S13). In the NOESY spectrum of 2 (Supplementary Figure S14 $)$, the obvious cross signals of $\mathrm{H}-2\left(\delta_{\mathrm{H}} 4.70\right) / \mathrm{H}-$ $25\left(\delta_{\mathrm{H}} 1.16\right), \mathrm{H}-2\left(\delta_{\mathrm{H}} 4.70\right) / \mathrm{H}-23\left(\delta_{\mathrm{H}} 1.11\right), \mathrm{H}-5\left(\delta_{\mathrm{H}} 2.35\right) /$ $\mathrm{H}-24\left(\delta_{\mathrm{H}} 4.24\right)$ and $\mathrm{H}-3\left(\delta_{\mathrm{H}} 4.13\right) / \mathrm{H}-5\left(\delta_{\mathrm{H}} 2.35\right)$ further confirmed the stereochemistries of $\mathrm{H}-2, \mathrm{H}-3$ and the presence of an oxygen atom connected to C-24. All the spectroscopic data in 2 were very similar to $2 \alpha, 3 \beta, 24-$ trihydroxy-olean-13-en-28-oic acid. ${ }^{14}$ The sugar chain at $\mathrm{C}-28$ of the aglycone was verified by the following important $\mathrm{HMBC}$ and ${ }^{1} \mathrm{H}-{ }^{1} \mathrm{H} \quad \mathrm{COSY}$ correlations (Supplementary Figures $\mathrm{S} 13$ and $\underline{\mathrm{S} 15}$ ) from H-1' $\left(\delta_{\mathrm{H}}\right.$ 6.123) of Glc-1' to C-28 ( $\left.\delta_{\mathrm{C}} 177.2\right), \mathrm{H}-1^{\prime \prime}\left(\delta_{\mathrm{H}} 5.02\right)$ of Glc-1" to C-4' $\left(\delta_{\mathrm{C}} 71.9\right)$ of Glc-1", and H-1"' $\left(\delta_{\mathrm{H}} 5.84\right)$ of Rha to C-4" ( $\left.\delta_{\mathrm{C}} 78.9\right)$ of Glc-1" (Figure 2). Finally, compound 2 was established as $2 \alpha, 3 \beta, 24$-trihydroxy-olean13-en-28-oic acid 28-O- $\alpha-\mathrm{L}$-rhamnopyranosyl-( $1 \rightarrow 4)-\mathrm{O}-$ $\beta$-D-glucopyranosyl-(1 $\rightarrow 4)$-O- $\beta$-D-glucopyranosyl ester. 
Table 3 NMR Data for Compounds $I$ and 2 (in $C_{5} D_{5} N, \delta$ in ppm, J in Hz)

\begin{tabular}{|c|c|c|c|c|}
\hline \multirow[t]{2}{*}{ No. } & \multicolumn{2}{|r|}{$\mathbf{I}$} & \multicolumn{2}{|r|}{2} \\
\hline & ${ }^{13}$ C-NMR & 'H-NMR & ${ }^{13}$ C-NMR & 'H-NMR \\
\hline I & 50.9 & $\mathrm{I} .47,2.38, \mathrm{~m}$ & 49.0 & $\mathrm{I} .85, \mathrm{I} .8 \mathrm{I}, \mathrm{m}$ \\
\hline 2 & 69.5 & $4.65, \mathrm{~m}$ & 69.9 & $4.70, \mathrm{~m}$ \\
\hline 3 & 78.7 & $4.08, \mathrm{~m}, J=3.89,11.53 \mathrm{~Hz}$ & 79.1 & $4.13, \mathrm{~m}, J=3.89,11.53 \mathrm{~Hz}$ \\
\hline 4 & 44.9 & - & 44.6 & - \\
\hline 5 & 49.1 & $1.98, \mathrm{~m}$ & 49.1 & $2.35, \mathrm{~m}$ \\
\hline 6 & 67.9 & 5.07, m & 34.1 & $\mathrm{I} .70, \mathrm{~m}$ \\
\hline 7 & 41.8 & $\mathrm{I} .85, \mathrm{~m}, 2.0 \mathrm{I}, \mathrm{m}$ & 31.7 & $1.38, \mathrm{~m}$ \\
\hline 8 & 40.4 & - & 43.5 & - \\
\hline 9 & 49.1 & I.96, m & 48.8 & $\mathrm{I} .40, \mathrm{~m}$ \\
\hline 10 & 38.6 & - & 39.3 & - \\
\hline II & 24.4 & $1.28, \mathrm{~m}$ & 24.8 & 2.07, m \\
\hline 12 & 126.8 & $5.5 \mathrm{I}, \mathrm{d}, J=6.8 \mathrm{~Hz}$ & 126.9 & $5.44, \mathrm{t}, J=6.2 \mathrm{~Hz}$ \\
\hline 13 & 138.2 & - & 139.4 & - \\
\hline 14 & 43.6 & - & 41.2 & - \\
\hline 15 & 29.3 & $\mathrm{I} .13, \mathrm{~m}, 2.49, \mathrm{~m}$ & 29.6 & I.37, m, 2.44, m \\
\hline 16 & 25.2 & $\mathrm{I} .16, \mathrm{~m}, 2.03, \mathrm{~m}$ & 25.5 & $\mathrm{I} .4 \mathrm{I}, \mathrm{m}, \mathrm{I.98, \textrm {m }}$ \\
\hline 17 & 48.9 & - & 49.3 & - \\
\hline 18 & 53.8 & $2.49, \mathrm{~s}$ & 54.1 & $2.5 \mathrm{I}, \mathrm{s}$ \\
\hline 19 & 39.5 & $0.86, \mathrm{~s}$ & 40.2 & $1.42, \mathrm{~s}$ \\
\hline 20 & 39.9 & I.38, m & 40.0 & I.37, m \\
\hline 21 & 31.3 & I.39, m & 31.7 & $\mathrm{I} .24, \mathrm{I} .44, \mathrm{~m}$ \\
\hline 22 & 37.2 & I.75, m, I.92, m 4.04 overlap & 37.8 & I.79, m, I.95, m 4.04 overlap \\
\hline 23 & 16.6 & $1.82, \mathrm{~s}$ & 15.3 & $\mathrm{I} . \mathrm{II}, \mathrm{s}$ \\
\hline 24 & 66.6 & $4.06, \mathrm{~m}, 4.4 \mathrm{I}, \mathrm{m}$ & 67.4 & $3.74, \mathrm{~m}, 4.24, \mathrm{~m}$ \\
\hline 25 & 18.8 & $\mathrm{I} .74, \mathrm{~s}$ & 18.7 & $1.16, \mathrm{~s}$ \\
\hline 26 & 17.8 & $0.93, \mathrm{~s}$ & 18.6 & $1.21, \mathrm{~s}$ \\
\hline 27 & 24.2 & $1.09, \mathrm{~s}$ & 24.6 & I.II, s \\
\hline 28 & 176.2 & - & 177.2 & - \\
\hline 29 & 21.7 & $0.86, d$ & 18.3 & $0.93, d, J=3.12 \mathrm{~Hz}$ \\
\hline 30 & 18.8 & $\mathrm{I} .72, \mathrm{~s}$ & 22.2 & $0.89, \mathrm{~d}, J=2.40 \mathrm{~Hz}$ \\
\hline Glc-I' & 96.9 & $6.13, \mathrm{~d}, J=7.8 \mathrm{~Hz}$ & 96.6 & $6.23, \mathrm{~d}, J=8.2 \mathrm{~Hz}$ \\
\hline $2^{\prime}$ & 74.2 & $4.13, \mathrm{~m}$ & 74.9 & $4.17, \mathrm{~m}$ \\
\hline $3^{\prime}$ & 79.0 & 4.24, m & 79.1 & $4.16, \mathrm{~m}$ \\
\hline $4^{\prime}$ & 71.5 & $4.28, \mathrm{~m}$ & 71.9 & 4.34, m \\
\hline $5^{\prime}$ & 76.9 & $4.13, \mathrm{~m}$ & 79.7 & $4.26, \mathrm{~m}$ \\
\hline $6^{\prime}$ & 61.8 & $4.08, \mathrm{~m}, 4.2 \mathrm{I}, \mathrm{m}$ & 70.4 & $4.29, \mathrm{~m}, 4.30, \mathrm{~m}$ \\
\hline Glc-I" & 105.4 & $4.96, \mathrm{~d}, J=1.8 \mathrm{~Hz}$ & 105.9 & $5.02, \mathrm{~d}, J=7.8 \mathrm{~Hz}$ \\
\hline $2^{\prime \prime}$ & 75.8 & $3.94, \mathrm{~m}$ & 76.3 & $4.00, \mathrm{~m}$ \\
\hline $3^{\prime \prime}$ & 78.3 & $4.39, \mathrm{~m}$ & 77.5 & $4.20, \mathrm{~m}$ \\
\hline $4^{\prime \prime}$ & 78.8 & $4.19, \mathrm{~m}$ & 78.9 & $4.48, \mathrm{~m}$ \\
\hline $5^{\prime \prime}$ & 77.6 & $3.66, \mathrm{~m}$ & 78.1 & 3.7I, m \\
\hline 6" & 69.9 & $4.43, \mathrm{~m}$ & 62.6 & $4.12, \mathrm{~m}, 4.28, \mathrm{~m}$ \\
\hline Rha-I"' & 102.7 & 5.84 , brs & 103.6 & 5.92 , brs \\
\hline $2^{\prime \prime \prime}$ & 73.0 & 4.67, m & 73.7 & 4.72, m \\
\hline $3^{\prime \prime \prime}$ & 73.2 & 4.54, m & 73.5 & $4.60, \mathrm{~m}$ \\
\hline $4^{\prime \prime \prime}$ & 74.5 & 4.33, m & 74.7 & 4.37, m \\
\hline $5^{\prime \prime \prime}$ & 70.8 & $4.93, \mathrm{~m}$ & 71.2 & $5.03, \mathrm{~m}$ \\
\hline 6"' & 19.8 & I.69, d, J $=6.4 \mathrm{~Hz}$ & 19.5 & $1.75, \mathrm{~d}, J=6.4 \mathrm{~Hz}$ \\
\hline
\end{tabular}




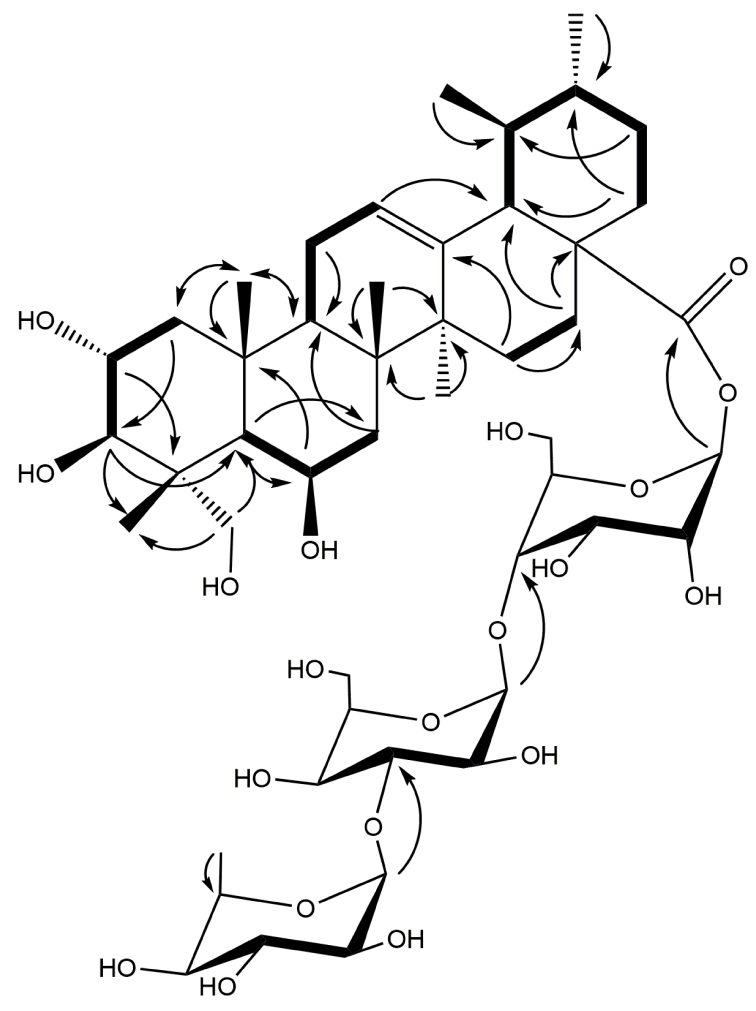

1

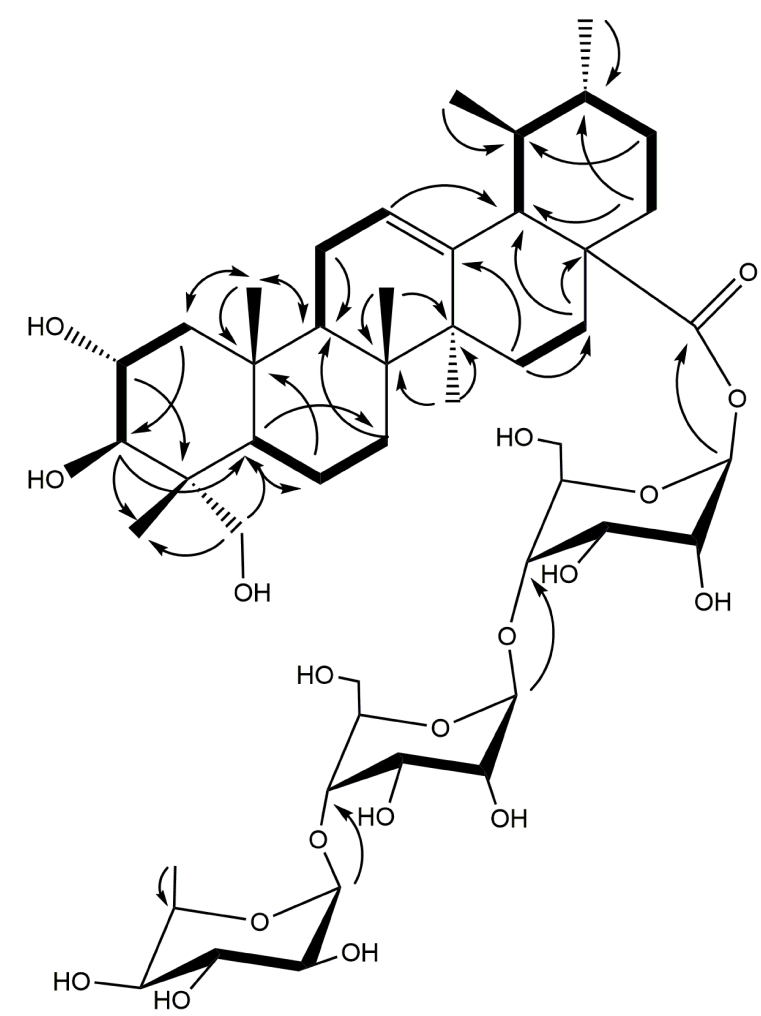

2

Figure 3 Key HMBC ( $(\longrightarrow)$ and $\mathrm{IH}-\mathrm{IH} \operatorname{COSY}(\frown)$ correlations of compounds I and 2.

\section{$\alpha$-Amylase Inhibition and Molecular Docking of I and 2}

In the present study, compounds $\mathbf{1}$ and $\mathbf{2}$ were evaluated for their inhibitory effects against $\alpha$-amylase (Table 4). Even though, the structures of $\mathbf{1}$ and $\mathbf{2}$ were very similar, the $\alpha$ amylase inhibitory effects were a little bit different. Thus, figuring out the structure-activity relationship (SAR) of these triterpene saponins will benefit structure modification of natural product. In order to demonstrate the potential of mechanism of these compounds, molecular docking of the compounds was performed against $\alpha$-amylase (1DHK). Interestingly, the binding energy of $\mathbf{1}$ was higher than that of 2 (Table 4), which was consistent with the $\alpha$-amylase inhibition effect. To further visualize the binding site, the interaction models of triterpene saponins with 1DHK are

Table $4 \alpha$-Amylase Inhibition and Binding Energy of $\mathbf{I}$ and 2

\begin{tabular}{|l|c|c|}
\hline Name & I & $\mathbf{2}$ \\
\hline$\alpha$-Amylase inhibition (I39 $\mathrm{gg} / \mathrm{mL})(\%)$ & $5 \mathrm{I} .9 \pm 2.8$ & $38.1 \pm 2.2$ \\
Binding energy (kal/mol) & -9.4 & -7.8 \\
\hline
\end{tabular}

shown in Figure 4. The analysis suggests that there were four amino acid residues $\left(\mathrm{Ser}^{289}, \mathrm{Pro}^{332}, \mathrm{Asp}^{402}, \mathrm{Arg}^{398}\right)$ in the active site of $1 \mathrm{DHK}$ interacting with $\mathbf{1}$ by hydrogen bonding (Figure 4A), while compound 2 bounded with three amino acid resides $\left(\mathrm{Ser}^{289}, \mathrm{Pro}^{332}, \mathrm{Arg}^{421}\right)$ of $1 \mathrm{DHK}$ (Figure 4B), suggesting that the predicted number of side chains of $1 \mathrm{DHK}$ active site involved in the binding interaction with a triterpene saponins is necessarily correlated with the binding affinity of the triterpene saponins to the enzyme.

\section{Discussion}

Diabetes mellitus (DM) is a type of metabolic disease caused by impaired insulin action or insufficient secretion. It is mainly caused by metabolic disorders of sugar, fat, and protein. ${ }^{15}$ It is characterized by persistent elevated blood sugar and accompanied by the occurrence of multi-system and multi-organ complications. Starch, derived from various food, is the main source of blood sugar, which can be absorbed after $\alpha$-amylase hydrolysis to generate monosaccharides. ${ }^{16} \alpha$-Amylase is mainly originated from the pancreas, stomach, and small intestine and has an important influence on the structure of glycosyls, which can hydrolyze the glycosidic bonds in various 
A

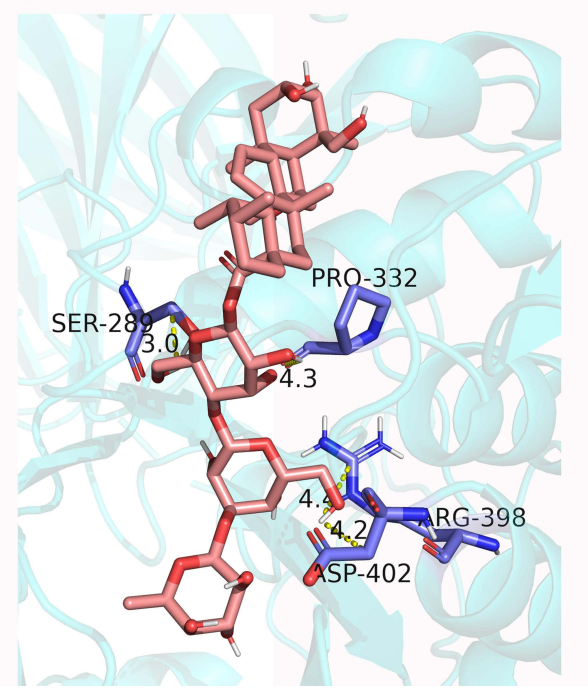

B

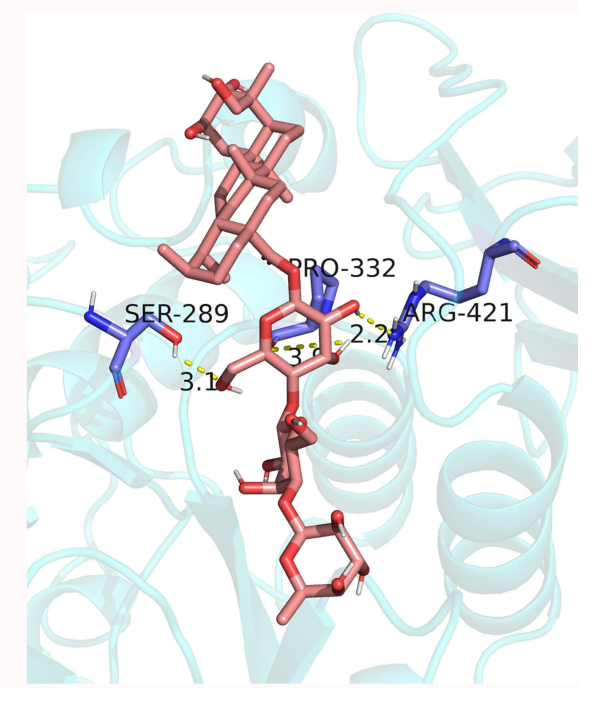

Figure 4 Molecular docking for binding interactions between compound I (A), compound 2 (B) and $\alpha$-amylase.

sugar-containing compounds by endo or exocytosis. ${ }^{17}$ Therefore, $\alpha$-amylase is a key enzyme that regulates postprandial blood sugar for the treatment of diabetes. In this study, bioguided isolation of $P$. capitatum, based on $\alpha$-glucosidase and $\alpha$ amylase inhibition screening, yielded two new triterpenoid saponins. Moreover, the potential binding sites of these triterpenoid saponins for $\alpha$-amylase was evaluated according to molecular docking analysis, which might be useful for structure modification of triterpenoid saponins for attenuating blood sugar level.

Starch digestibility has been reported to relate to elevated postprandial blood glucose. One of the strategies to reduce postprandial hyperglycemia is to limit the activity of carbohydrate digestive enzymes in the intestinal tract. $\alpha$-Amylase is the key enzyme that degrades the polymeric substrate into shorter oligomers by catalyzing the hydrolysis of $\alpha-1,4$-glucan linkages present in starch, maltodextrins, and other related carbohydrates. $^{18}$ Thus, pursuing efficient $\alpha$-amylase inhibitor can reduce the high frequency of postprandial hyperglycaemia in diabetes. Due to the highly abundant compounds in nature and for their promising biological activities, plants offer excellent alternatives to manage postprandial hyperglycaemia via inhibiting $\alpha$-amylase. Polygonum capitatum belongs to the Polygonaceae, genus Polygonum, and has been reported to be involved in clearing heat and draining dampness in TCM theory, which might be associated with hypoglycemia. In our research, we used $\alpha$-amylase inhibitory experiment to guided separate active ingredients in $P$. capitatum. Compared with the whole plant extract, the n-butanol fractioned part showed more $\alpha$-amylase inhibitory activities. Thus, $n$-butanol fractioned part was selected to investigate the active ingredients of $P$. capitatum.

After careful isolation of the n-butanol part, two new triterpenoid saponins were identified. Previous studies have revealed various triterpenoids exhibited $\alpha$-glucosidase inhibitory activity. In addition, structure-activity relationship (SAR) analysis indicated that the side chain structure plays a major role in the inhibition of $\alpha$-glucosidase activity. ${ }^{19}$ Based on this hypothesis, Nie et al constructed a linkage between oleanolic acid and cinnamic amides, and showed strong $\alpha$-glucosidase inhibitory activity. ${ }^{20}$ In our research, the side chains (three sugar groups) in $\mathbf{1}$ and $\mathbf{2}$ were binding to amino acid residues of $\alpha$-amylase, which was consistent to the previous study after molecular docking analysis. ${ }^{19}$

Molecular docking analysis suggested that the interaction of hydrogen between amino acid residue and triterpenoid saponins may play an important role in inhibiting amylase (Figure 4). Previous X-crystal studies of $\alpha$-amylase have revealed various amino acid residues $\left(\mathrm{Asp}^{197}, \mathrm{Glu}^{233}\right.$ and $\mathrm{Asp}^{300}$ ) were thought to be important residue for $\alpha$-amylase catalysis, in which $\mathrm{Asp}^{197}$ was considered a catalytic nucleophilic reagent in the process of starch hydrolysis, while Asp ${ }^{300}$ is mainly used for substrate orientation optimization. ${ }^{21-23}$ In the study of the binding properties of the compound 1 (Figure 4), the hydrogen at H-6" forms connections both with $\mathrm{Arg}^{398}$ and $\mathrm{Asp}^{402}$, while two hydrogen bond contacts with $\mathrm{Ser}^{289}$ and Pro ${ }^{332}$ in Glc-1'. Meanwhile, Figure 3B shows the binding properties of the compound 2, where two hydrogen bond contacts with $\mathrm{Ser}^{289}$, $\mathrm{Pro}^{332}$, and $\mathrm{Arg}^{421}$ in Glc-1'. Comparison the structures between $\mathbf{1}$ and $\mathbf{2}$, both hydrogen at 
H-6' in Glc- $1^{\prime}$ formed connection with Ser $^{289}$ and Pro $^{33}$. However, 1,4-glycosidic bond in $\mathbf{2}$ forms a more rigid structure than 1,3-glycosidic bond of $\mathbf{1}$, which made a greater distance from the active site $\left(\mathrm{Asp}^{402}\right)$. Overall, the in silico analysis of the ligand-protein interaction of new triterpenoid saponins with amino acid residues gave credence to the inhibitory effect of triterpenoid saponins reported in this study.

\section{Conclusion}

We used $\alpha$-amylase and $\alpha$-amylase screening method to guide isolation of two novel triterpenoid saponins (1 and 2) from the n-butanol fractioned part of $P$. capitatum. Both compounds showed $\alpha$-amylase inhibitory effect, even though there was a little activity difference for them. Docking simulation and binding affinity experiments revealed that compound $\mathbf{1}$ was more effective in inhibiting $\alpha$-amylase, and revealed a possible mechanism of $\mathbf{1}$ and $\mathbf{2}$ in $\alpha$-amylase inhibition. Moreover, the active group of $\mathbf{1}$ and $\mathbf{2}$ in $\alpha$-amylase inhibition might provide a new sight of structural modification of triterpenoid saponins in screening active compounds of $\alpha$-amylase inhibition.

\section{Acknowledgments}

The authors acknowledge the School of Pharmacy in Second Military Medical University for the support.

\section{Funding}

This research project was supported by the National Key R\&D Program of China (2019YFC1711000).

\section{Disclosure}

The authors report no conflicts of interest in this work.

\section{References}

1. Ceriello A. Postprandial hyperglycemia and diabetes complications: is it time to treat? Diabetes. 2005;54(1):1-7. doi:10.2337/diabetes.54.1.1

2. Mata R, Cristians S, Escandón-Rivera S, Juárez-Reyes K, Rivero-Cruz I. Mexican antidiabetic herbs: valuable sources of inhibitors of $\alpha$-glucosidases. J Nat Prod. 2013;76(3):468-483. doi:10.1021/np300869g

3. Kajaria D, Ranjana TJ, Tripathi YB, Tiwari S. In-vitro $\alpha$ amylase and glycosidase inhibitory effect of ethanolic extract of antiasthmatic drug - Shirishadi. J Adv Pharm Technol Res. 2013;4(4):206-209. doi:10.4103/2231-4040.121415

4. Tan Y, Chang SKC, Zhang Y. Comparison of $\alpha$-amylase, $\alpha$-glucosidase and lipase inhibitory activity of the phenolic substances in two black legumes of different genera. Food Chem. 2017;214:259-268. doi:10.1016/j.foodchem.2016.06.100

5. Inzucchi SE, Matthews DR, et al; Response to Comments on Inzucchi. Management of hyperglycemia in type 2 diabetes, 2015: a patientcentered approach. Update to a position statement of the American diabetes Association and the European Association for the Study of diabetes. Diabetes Care 2015;38:140-149. Diabetes Care. 2015;38(8): e128-e129. doi:10.2337/dc15-0812
6. Hanefeld M. Cardiovascular benefits and safety profile of acarbose therapy in prediabetes and established type 2 diabetes. Cardiovasc Diabetol. 2007;6:20. doi:10.1186/1475-2840-6-20

7. Kim KY, Nam KA, Kurihara H, Kim SM. Potent alpha-glucosidase inhibitors purified from the red alga grateloupia elliptica. Phytochemistry. 2008;69(16):2820-2825. doi:10.1016/j. phytochem.2008.09.007

8. Ortiz-Andrade RR, García-Jiménez S, Castillo-España P, RamírezAvila G, Villalobos-Molina R, Estrada-Soto S. alpha-glucosidase inhibitory activity of the methanolic extract from tournefortia hartwegiana: an anti-hyperglycemic agent. $J$ Ethnopharmacol. 2007;109 (1):48-53. doi:10.1016/j.jep.2006.07.002

9. Liu BY, Tong NS, Li YY, Huang SW. Hypoglycemic mechanism of Polygonum capitatum extract on spontaneous model of type 2 diabetic db/db mice. Chin Pharm J. 2017;52(5):384-390.

10. Chen BQ, Li CQ, Chang X, Kang WY. Inhibitory activity of polygonum capitatum to $\alpha$-glucosidase. Chin J Exp Tradit Med Form. 2010;16(8):151-153.

11. Ye QZHG, Huang DD, Lv SS, Wu ZJ, Sun LN. Studies on lignans of Polygonum capitatum and their hypoglycemic activity. J Chin Med Mater. 2017;40(1):107-110.

12. Kazeem MI, Mayaki AM, Ogungbe BF, Ojekale AB. Studies on leaf extracts as inhibitors of key enzymes linked to diabetes mellitus. Iran J Pharm Res. 2016;15(Suppl):37-44.

13. Kenfack JN, Ponou BK, Jonas T, et al. A new flavonol glycoside from tristemma hirtum (melastomataceae). Nat Prod Res. 2018;28 (3):213. doi:10.20307/nps.2018.24.3.213

14. Ren B, Luo W, Xie MJ, Zhang M. Two new triterpenoid saponins from centella asiatica. Phytochem Lett. 2021;44:102-105. doi:10.1016/j.phytol.2021.06.012

15. Luo Z, Fu C, Li T, et al. Hypoglycemic effects of licochalcone A on the streptozotocin-induced diabetic mice and its Mechanism Study. $J$ Agric Food Chem. 2021;69(8):2444-2456. doi:10.1021/acs. jafc.0c07630

16. Zeng X-Y, Wang Y-P, Cantley J, et al. Oleanolic acid reduces hyperglycemia beyond treatment period with Akt/FoxO1-induced suppression of hepatic gluconeogenesis in type-2 diabetic mice. PLoS One. 2012;7(7):e42115. doi:10.1371/journal.pone.0042115

17. Moorthy NSHN, Ramos MJ, Fernandes PA. Topological, hydrophobicity, and other descriptors on $\alpha$-glucosidase inhibition: a QSAR study on xanthone derivatives. J Enzyme Inhib Med Chem. 2011;26 (6):755-766. doi:10.3109/14756366.2010.549089

18. Vocadlo DJ, Davies GJ. Mechanistic insights into glycosidase chemistry. Curr Opin Chem Biol. 2008;12(5):539-555. doi:10.1016/j. cbpa.2008.05.010

19. Tchoukoua A, Tomfeun Nganou SC, Dabole B, et al. Polythosides A and $\mathrm{B}$, two new triterpenoid saponins from the roots of acacia polyacantha Willd. (Mimosaceae). Phytochem Lett. 2021;43:190-195. doi:10.1016/j.phytol.2021.04.007

20. Nie W, Luo J-G, Wang X-B, et al. Synthesis of new $\alpha$-glucosidase inhibitors based on oleanolic acid incorporating cinnamic amides. Chem Pharm Bull. 2011;59(8):1051-1056. doi:10.1248/cpb.59.1051

21. MacGregor EA, Janecek S, Svensson B. Relationship of sequence and structure to specificity in the alpha-amylase family of enzymes. Biochim Biophys Acta. 2001;1546(1):1-20. doi:10.1016/s0167-4838 (00)00302-2

22. Alqahtani AS, Hidayathulla S, Rehman MT, et al. Alpha-amylase and alpha-glucosidase enzyme inhibition and antioxidant potential of 3oxolupenal and katononic acid isolated from. Biomolecules. 2019;10 (1):61. doi:10.3390/biom10010061

23. Kikiowo B, Ogunleye JA, Iwaloye O, Ijatuyi TT. Therapeutic potential of Chromolaena odorata phyto-constituents against human pancreatic $\alpha$-amylase. J Biomol Struct Dyn. 2020;1-12. doi:10.1080/ 07391102.2020.1833758 


\section{Publish your work in this journal}

Drug Design, Development and Therapy is an international, peerreviewed open-access journal that spans the spectrum of drug design and development through to clinical applications. Clinical outcomes, patient safety, and programs for the development and effective, safe, and sustained use of medicines are a feature of the journal, which has also been accepted for indexing on PubMed Central. The manuscript management system is completely online and includes a very quick and fair peer-review system, which is all easy to use. Visit http://www. dovepress.com/testimonials.php to read real quotes from published authors.

Submit your manuscript here: https://www.dovepress.com/drug-design-development-and-therapy-journal 